\title{
Additional factors influencing resident satisfaction and dissatisfaction
}

This article was published in the following Dove Press journal:

Advances in Medical Education and Practice

10 November 2017

Number of times this article has been viewed

\section{Seyed Ramin Jalal \\ Abdirahman Osman \\ Saeed Azizi}

Faculty of Medicine, St George's Hospital Medical School, London, UK
Correspondence: Seyed Ramin Jalal

Faculty of Medicine, St George's Hospital

Medical School, Cranmer Terrace,

London SWI7 ORE, UK

Tel +44795073 I276

Email ramin_vdjala19@hotmail.com

\section{Dear editor}

We have read the recent review article by Kahn et $\mathrm{al}^{1}$ with great interest. The original article was detailed and informative, and we felt it would be helpful to expand on the factors affecting resident satisfaction and dissatisfaction. As senior medical students in clinical years, we spend a significant portion of our time shadowing specialist trainees. Thus, we can offer a unique perspective on the factors affecting trainee satisfaction and well-being.

We firstly commend the authors for attempting to identify the factors affecting residency satisfaction and dissatisfaction. Notable associations which were correlated with residency dissatisfaction were highlighted, including wanting "more or much more" time available to spend with family and insufficient patient interactions. ${ }^{1}$ It was found that $\sim 40 \%$ of the participants reported wanting to spend more time with family. ${ }^{1}$ $\mathrm{Lu}$ et $\mathrm{al}^{2}$ similarly found that satisfaction among health care staff was increased by balancing adequate time between work and family. We believe that Lu et al's ${ }^{2}$ study may be extrapolated to other cohorts, including medical students.

There were a number of important predictors of satisfaction which were not explored by the authors. One predictor of satisfaction is the impact of travel duration. In 2014, the Office for National Statistics examined the relationship between commuting and personal well-being $;{ }^{3}$ it was concluded that a 10 -minute increase in commuting time was reflected by a notable reduction in satisfaction. One could argue that commuting time is a confounder for other factors, such as the time available for family. However, there is ample evidence that commuting itself is a work-related stressor.

Another important contributor to residency satisfaction is organizational culture, especially relationships between peers and seniors. The 2016 national training survey carried out by the General Medical Council in the UK reported that " 1 in 20 doctors in training said they had a bullying or undermining concern". ${ }^{4}$ Organizational culture not only has an impact on job satisfaction, but also on patient safety and clinical outcomes, as highlighted by Körner et al. ${ }^{5}$ The need for evaluating organizational culture should not be understated due to its substantial influence on trainee satisfaction. Attaining a better, but not wholesome understanding of organizational culture can be through formulating appropriate questions for residents or trainees on their perspectives of their workplace environment.

In order to determine the components influencing satisfaction and dissatisfaction of the residency program, we believe further research focusing on broader elements 
within the residency program is needed. Attempting to quantitatively determine the influence of aforementioned factors is a difficult task, but one which we believe will be helpful for residency organizers to consider in the future.

\section{Disclosure}

The authors report no conflicts of interest in this communication.

\section{References}

1. Kahn JS, Witteles RM, Mahaffey KW, Desai SA, Ozdalga E, Heidenreich PA. A 15-year review of the Stanford internal medicine residency program: predictors of resident satisfaction and dissatisfaction. Adv Med Educ Pract. 2017;8:559-566.
2. Lu Y, Hu XM, Huang XL, et al. Job satisfaction and associated factors among healthcare staff: a cross-sectional study in Guangdong Province, China. BMJ Open. 2016;6(7):e011388.

3. Does commuting affect well-being? [webpage on the Internet]. London: Office for National Statistics; 2014 [released February 12, 2014]. Available from: http://webarchive.nationalarchives.gov.uk/20160107113203/ http://www.ons.gov.uk/ons/rel/wellbeing/measuring-national-well-being/ commuting-and-personal-well-being--2014/sty-commuting-and-wellbeing.html. Accessed November 3, 2017.

4. General Medical Council. National training survey 2016. Manchester: General Medical Council; 2016. Available from: http://www.gmc-uk. org/National_training_survey_2016__key_findings_68462938.pdf. Accessed November 3, 2017.

5. Körner M, Wirtz MA, Bengel J, Göritz AS. Relationship of organizational culture, teamwork and job satisfaction in interprofessional teams. $B M C$ Health Serv Res. 2015;15:243.

Dove Medical Press encourages responsible, free and frank academic debate. The content of the Advances in Medical Education and Practice 'letters to the editor' section does not necessarily represent the views of Dove Medical Press, its officers, agents, employees, related entities or the Advances in Medical Education and Practice editors. While all reasonable steps have been taken to confirm the content of each letter, Dove Medical Press accepts no liability in respect of the content of any letter, nor is it responsible for the content and accuracy of any letter to the editor.

\section{Publish your work in this journal}

Advances in Medical Education and Practice is an international, peerreviewed, open access journal that aims to present and publish research on Medical Education covering medical, dental, nursing and allied health care professional education. The journal covers undergraduate education, postgraduate training and continuing medical education including emerging trends and innovative models linking education, research, and health care services. The manuscript management system is completely online and includes a very quick and fair peer-review system. Visit http://www.dovepress.com/testimonials.php to read real quotes from published authors.

Submit your manuscript here: http://www.dovepress.com/advances-in-medical-education-and-practice-journal 